\title{
PENGEMBANGAN MEDIA PEMBELAJARAN 16 TENSES BAHASA INGGRIS BERBASIS ANDROID
}

\author{
Nelly Rosaline ${ }^{1}$, I ketut Setiawan ${ }^{2}$ \\ 1,2Program Studi Teknologi Informatika, STMIK STIKOM Indonesia \\ Jl. Tukad Pakerisan No.97, Panjer, Denpasar Selatan, Kota Denpasar, Bali 80225 Indonesia \\ nellyrosaline28@gmail.com ${ }^{1}$,wen@stiki-indonesia.ac.id ${ }^{2}$
}

\begin{abstract}
Abstrak: Indonesia berada di peringkat ke-74 dari 100 negara dan berada dalam kategori rendah dalam EF EPI 2020 (Education First English Proficiency Index. Tata bahasa dan bentuk kata menjadi komponen dasar dalam penggunaan Bahasa Inggris. Penelitian ini bertujuan untuk merancang, membuat, dan mengimplementasikan pembelajaran 16 tenses Bahasa Inggris untuk mahasiswa. Media pembelajaran tersebut akan memberikan tabel dan penjelasan 16 tenses dalam Bahasa Inggris, contoh kalimat dan latihan soal dalam bentuk kuis dilengkapi dengan kalimat pelafalan untuk melatih kemampuan mendengarkan. Metode pengumpulan data yang digunakan adalah wawancara, kuesioner, dokumentasi dan kepustakaan. Aplikasi yang dibuat berbasis Android yang bisa diunduh di dalam Google Play. Berdasarkan hasil evaluasi 50 mahasiswa menyatakan bahwa dari segi materi $91,9 \%$ mudah dipahami, dari segi UI 97,6\% menarik untuk digunakan, dari segi UX 90,8\% mudah digunakan. Berdasarkan hasil evaluasi 3 dosen Bahasa Inggris yang diwawancarai dalam penelitian ini dapat disimpulkan bahwa $83,7 \%$ materi sudah sesuai sesuai untuk tingkat mahasiswa, dari segi UI 86,7\% menarik untuk digunakan, dari segi UX 91,7\% mudah dan direkomendasikan untuk digunakan sebagai media pendukung pembelajaran Bahasa Inggris di STMIK STIKOM Indonesia.
\end{abstract}

Kata kunci: Media pembelajaran, Tenses Bahasa Inggris, Aplikasi Android

Abstract: Indonesia is ranked 74 out of 100 countries and is in the low category in the EF EPI 2020 (Education First English Proficiency Index). Grammar and tenses are the basic components in English. This study aims to design, create, and implement learning 16 English tenses for college students. The learning media will provide tables and explanations of 16 tenses in English, sentence examples and exercises in the form of quizzes equipped with pronunciation sentences to practice listening skills. The data collection methods used were interviews, questionnaires, documentation and literature. The application is made based on Android that can be downloaded on Google Play. Based on the results of 50 college students' evaluation, it stated that in terms of material, $91,9 \%$ was easy to understand, while in terms of $\mathrm{UI}, 97.6 \%$ was interesting to use, and in terms of UX, 90,8\% was easy to use. Based on the interview results of 3 English lecturers in this study, it can be concluded that $83,7 \%$ of the material is suitable for the college student level, while in terms of $\mathrm{UI}, 86.7 \%$ is 
interesting to use, and in terms of UX. $91.7 \%$ is easy and recommended to be used as a supporting media for learning English at STMIK STIKOM Indonesia.

Keywords: Learning media, English Tenses, Android application

\section{PENDAHULUAN}

Pemerintah Indonesia menyiapkan langkah untuk menghadapi persaingan global. Dikutip dari berita CNN Indonesia (2019), Komite Ekonomi Industri Nasional (KEIN) merekomendasikan 4 industri potensial yang mampu dikembangkan Indonesia, 4 sektor tersebut meliputi industri agro, maritim, kreatif dan digital, serta industri pariwisata pada 7 Oktober 2019 dalam kegiatan 'FGD \& Business Meeting' di Institut Teknologi Sepuluh Nopember.

Karena tuntutan persaingan dunia, maka peningkatan keterampilan harus dilakukan. Salah satunya adalah keterampilan berbahasa asing, khususnya Bahasa Inggris. Menurut Ethnologue Languages of the World menyebutkan bahwa ada 146 negara menggunakan Bahasa Inggris, sehingga Bahasa Inggris menduduki posisi pertama bahasa yang paling banyak digunakan di dunia (EF Education First, 2019). Sementara di Indonesia sendiri penggunaan Bahasa Inggris tercatat berada pada urutan ke-74 dari 100 negara dan berada dalam kategori rendah dalam EF EPI 2020 (Education First English Proficiency Index).

Pelajaran Bahasa Inggris yang diajarkan meliputi mendengarkan, menulis, membaca dan berbicara. Selain itu juga, terdapat tiga elemen bahasa yang berperan penting dalam mendukung keempat keterampilan tersebut, yaitu pelafalan, kosa kata, dan struktur Bahasa (Megawati, 2016). Kendala atau masalah yang sering dihadapi dalam pendidikan Bahasa Inggris oleh peserta didik pada umumnya adalah pelajaran mengenai tenses, apalagi dunia saat ini sedang berada dalam situasi pandemi COVID-19 (Corona Virus Disease 2019), yang mengharuskan proses belajar mengajar dengan media online (Nuriansyah, 2020). 
Tenses merupakan bentuk kata kerja untuk menunjukkan waktu dan derajat tuntasnya suatu kegiatan atau keadaan, atau menunjukkan apakah suatu kegiatan itu sudah selesai, akan dikerjakan, atau sedang berlangsung dalam jangka waktu tertentu. Dengan kata lain Tenses mengacu pada bentukbentuk gramatikal (tata bahasa) dari kata kerja (verb) (Prastowo, 2016). Aplikasi ini akan memaparkan penjelasan 16 tenses, yaitu : (1) Simple Present Tense, (2) Present Continues Tense, (3) Present Perfet Tense, (4) Present Perfect Continues Tense, (5) Simple Present Tense, (6) Present Continues Tense, (7) Present Perfet Tense, (8) Present Perfect Continues Tense, (9) Simple Future Tense, (10) Future Continues Tense, (11) Future Perfet Tense, (12) Future Perfect Continues Tense, (13) Simple Past Future Tense, (14) Past Future Continues Tense, (15) Past Future Perfet Tense, (16) Past Future Perfect Continues Tense.

Berdasarkan hal tersebut, maka perlu dilakukan pengembangan terkait dengan media pembelajaran Bahasa Inggris khususnya mengenai tenses, sehingga akan mempermudah siswa dalam belajar, serta dengan metode yang menyenangkan. Selain itu media pembelajaran tentunya harus mampu menyalurkan pesan, dapat merangsang pikiran, perasaan, dan kemauan peserta didik sehingga dapat mendorong terciptanya proses belajar pada diri peserta didik (Ekayani, 2017; Kurniawati \& Nita, 2018).

Solusi pembuatan media pembelajaran 16 tenses Bahasa Inggris berbasis Android didasari oleh perkembangan teknologi khususnya smartphone yang semakin meningkat, sehingga memungkinkan proses pembelajaran menjadi lebih interaktif dengan menggunakan smartphone (Merliana, 2019). Selain itu juga, Kehadiran dan kemajuan smartphone di era komunikasi global dewasa ini telah memberikan peluang dan perluasan interaksi antara dosen atau pengajar atau pakar dan mahasiswa, antar mahasiswa, antara mahasiswa dan sumber-sumber belajar dapat terjadi 
kapan saja dan di mana saja tanpa dibatasi oleh ruang dan waktu (Putri \& Sahari, 2017).

Sebagai bahan pertimbangan dalam penelitian ini, dua penelitian terdahulu disajikan di sini. Penelitian pertama dilakukan oleh Susilawati dan Khadami (2016) di mana membahas mengenai pembuatan aplikasi pembelajaran dalam Bahasa Inggris untuk kelas 10 di SMKN 9 Bandung. Pada penelitian tersebut disimpulkan bahwa aplikasi ini digunakan sebagai alternatif untuk pembelajaran khususnya tenses, agar bisa lebih memahami dan juga bisa membantu kegiatan belajar.

Selanjutnya penelitian kedua dilakukan oleh Makmun (2017), yang mengatakan bahwa mempelajari tenses dengan membuka buku-buku Bahasa Inggris kurang praktis dan interaktif, sehingga dengan menggunakan platform Android diharapkan dapat membantu masyarakat khususnya anak-anak dan remaja sebagai media alternatif dalam sistem pembelajaran tanpa batasan waktu dan tempat.

Dari kedua penelitan yang sudah dilakukan tersebut belum ada yang menyinggung mengenai solusi untuk memotivasi pengguna dalam penggunaan bekelanjutan. Selain itu, pada penelitian oleh Makmun (2017) hanya menampilkan satu contoh kalimat dan satu contoh soal pada setiap tenses, dengan kata lain materi yang disajikan masih belum bervariatif. Hal senada juga terjadi pada penelitian oleh Susilawati dan Khamadi (2016) yang hanya menampilkan 12 jenis tenses dan tidak menampilkan contoh kalimat pada setiap tensesnya. Selain itu hasil aplikasi dari kedua penelitian tersebut masih menggunakan versi Android lama serta aplikasi belum diunggah ke Play Store untuk kemudahan pengguna dalam mengunduh aplikasi. 


\section{METODE PENELITIAN}

Penelitian ini menggunakan metode pengumpulan data primer yaitu observasi, wawancara dan kuesioner, serta pengumpulan data sekunder yaitu kepustakaan dan dokumentasi. Metode observasi dilakukan dalam salah satu unit kegiatan mahasiswa di STMIK STIKOM Indonesia berkenaan tentang peminatan Bahasa Inggris yaitu ECSI (English Club of STIKI Indonesia) yang beranggotakan 100 mahasiswa pada periode 2019/2020. Kegiatan ini dilakukan untuk melihat kondisi pembelajaran Bahasa Inggris yang berkenaan tentang tenses dan media apa yang digunakan saat pembelajaran dan penyampaian informasi dalam unit kegiatan mahasiswa tersebut.

Metode wawancara dilakukan kepada 3 dosen Bahasa Inggris di STMIK STIKOM Indonesia yaitu; Sri Widiastutik, S.S., M.Hum., Ni Putu Dian Indra Pratiwi, S.Pd., M.Pd., dan Kadek Yogi Susana, S.S., M.Hum. Wawancara dilakukan untuk mendapatkan informasi mengenai materi Bahasa Inggris yang diajarkan di dalam mata kuliah yang berlaku di STMIK STIKOM Indonesia dan media apa yang mendominasi dalam proses belajar mengajar.

Kuesioner juga dilakukan kepada 11 dosen Bahasa Inggris dan 50 mahasiswa di STMIK STIKOM Indonesia berkaitan tentang nilai dan kendala dalam pembelajaran Bahasa Inggris II sebelum dan sesudah adanya pembelajaran online.

Pada pengumpulan data sekunder, studi kepustakaan diperoleh dari buku yang berkaitan dengan penelitian yaitu penjelasan dan contoh tenses Bahasa Inggris. Metode dokumentasi yang digunakan sebagai data pendukung pada penelitian ini adalah data rekapan nilai mata kuliah Bahasa Inggris II dari BAAK STMIK STIKOM Indonesia pada semester genap dari tahun akademik 2018/2019 hingga 2019/2020.

Konsep visual dari aplikasi ini adalah semi formal dengan gaya kartunal yang dipadukan dengan gaya simpel dan flat desain. Gaya ini digunakan agar 
user interface dari aplikasi yang diwujudkan tidak terlalu kaku, serta sesuai dengan karakteristik dari penguna yaitu anak muda. Pada aplikasi juga menambahkan beberapa fitur tambahan yaitu kuis pilihan ganda dan menyusun kata untuk menguji pemahaman pengguna serta suara pelafalan kalimat dalam Bahasa Inggris untuk melatih kemampuan mendengarkan (Antare \& Setiawan, 2021). Aplikasi juga akan memberikan poin pada setiap soal yang terjawab sebagai motivasi penggunaan berkelanjutan.

\section{HASIL DAN DISKUSI}

Berdasarkan hasil observasi didapatkan informasi bahwa penyampaian materi tentang tenses pada unit kegiatan tersebut masih diajarkan secara konvensional. Hal tersebut dilakukan dengan pembagian kelompok presentasi oleh anggota grupnya dan media smartphone yang mendominasi digunakan dalam mencari informasi maupun saat mempresentasikan di depan kelas. Hal ini menjadi acuan untuk implementasi materi dan pemilihan media dalam penelitian.

Kesimpulan dari informasi yang didapat dalam proses wawancara adalah materi diberikan sesuai dengan RPS yang berlaku di STMIK STIKOM Indonesia, serta media pembelajaran yang digunakan masih menggunakan slide Microsoft Power Point. Materi yang berkenaan tentang tenses terdapat pada mata kuliah Bahasa Inggris II di pertemuan ke-4, ke-6, ke-12 dan ke-13, serta mahasiswa diberikan kebebasan untuk mencari informasi dan referensi melalui ponsel mereka masing-masing terkait tugas yang diberikan. Kesimpulan pada hasil kuesioner adalah adanya penurunan nilai Bahasa Inggris II selama pembelajaran online, dan tugas yang disetorkan oleh mahasiswa cenderung sama antara mahasiswa satu dengan yang lainnya. 


\section{Visualisasi Rancangan}

Media pembelajaran 16 tenses Bahasa Inggris berbasis Android pada penelitian ini memiliki alur menu sebagai berikut:

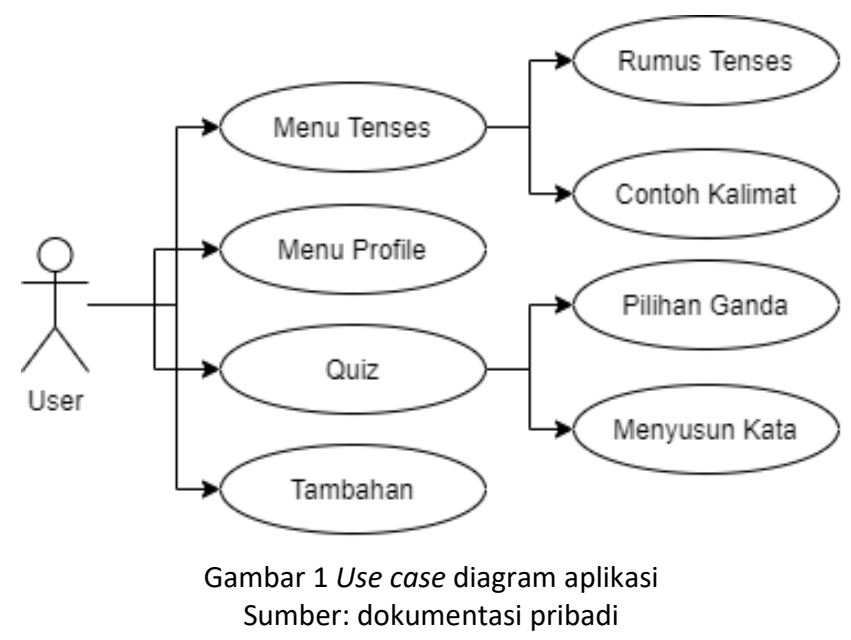

Pemilihan OS Android sebagai media solusi penelitian ini, karena Android merupakan sistem operasi dari berbagai merek ponsel, serta OS tersebut masih berada pada posisi pertama sistem operasi ponsel yang paling banyak digunakan seperti data yang ditunjukkan pada Gambar 2.

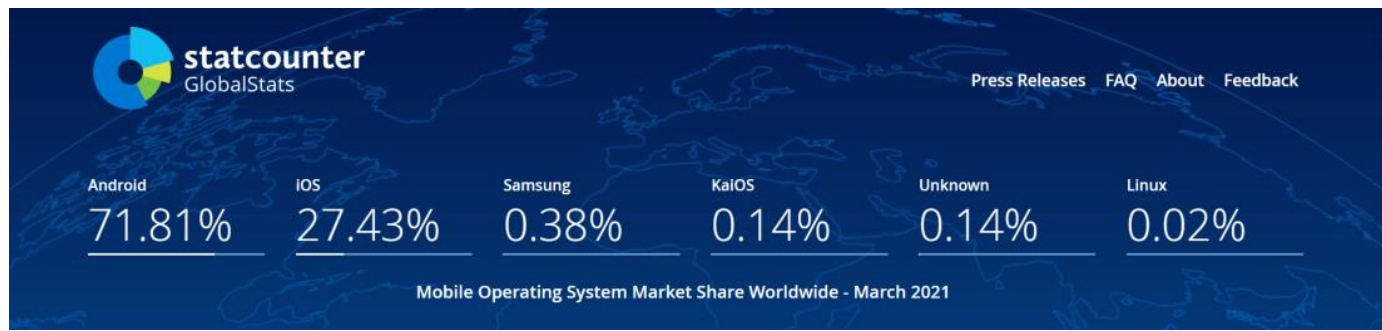

Gambar 2 Statistika pengguna sistem operasi mobile Sumber: Statcounter (2021)

Aplikasi memuat informasi tentang rumus kalimat setiap jenis tenses dan memuat 10 sampai 15 contoh kalimatnya. Aplikasi juga berisikan 2 jenis latihan soal, di mana pada latihan soal pilihan ganda memiliki 5 soal pada 
setiap tenses dan 3 soal pada latihan soal menyusun kata pada setiap tenses. Setiap soal yang ditampilkan memiliki fitur audio untuk melatih kemampuan mendengarkan.

Rasio tampilan didesain dengan ukuran 1080 x 1920 piksel dengan rasio layar 9:16. Orientasi aplikasi yang akan dibuat adalah portrait, untuk memudahkan pengguna dalam penggunaan atau menekan tombol (eksplorasi aplikasi) yang disajikan dengan hanya menggunakan satu tangan.

Warna yang digunakan dalam perancangan aplikasi ini adalah warnawarna intermediate dan warna-warna yang lembut. Pemilihan warna pastel yang lembut dimaksudkan untuk memberi kesan tenang dan tidak mencolok sehingga membuat pengguna tetap nyaman menatap dan menggunakan aplikasi. Pemilihan warna yang beragam juga dimaksudkan untuk memberikan kesan playful dalam aplikasi. Font yang akan digunakan adalah font jenis Sans-Serif, yaitu font Open Sans untuk menimbulkan kesan minimalis dan tetap mudah terbaca (Natalia \& Setiawan, 2020).

Perancangan desain untuk tata letak tampilan aplikasi dibuat dengan tata letak asimetris dan menggunakan banyak bidang kosong untuk memberikan kesan yang minimalis, bersih dan tegas (Putu, Dewi, \& Setiawan, 2020). Aplikasi media pembelajaran 16 Tenses Bahasa Inggris ini bernama Tenses App dengan tagline "More practices for better English". Aplikasi ini memiliki berat kapasitas sebesar 27 Mb. Gambar 3 sampai dengan Gambar 5 merupakan tampilan dari aplikasi Tenses App ini. 


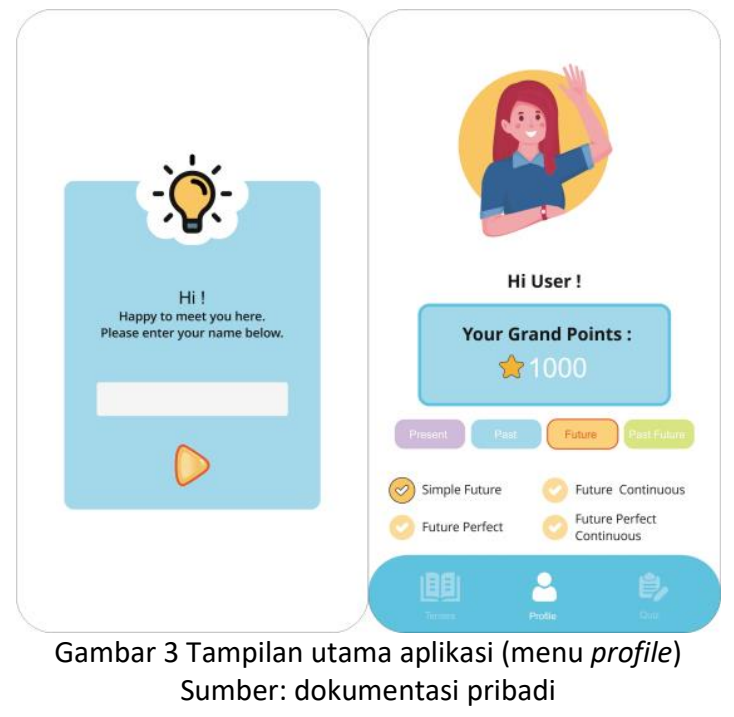

Gambar 3 menampilkan tampilan utama aplikasi di mana pengguna diharuskan mengisi nama untuk masuk ke dalam menu utama. Menu utama berisi karakter wanita yang sedang menyapa, jumlah perolehan nilai, dan tiga tombol akses yang berada pada bagian bawah.

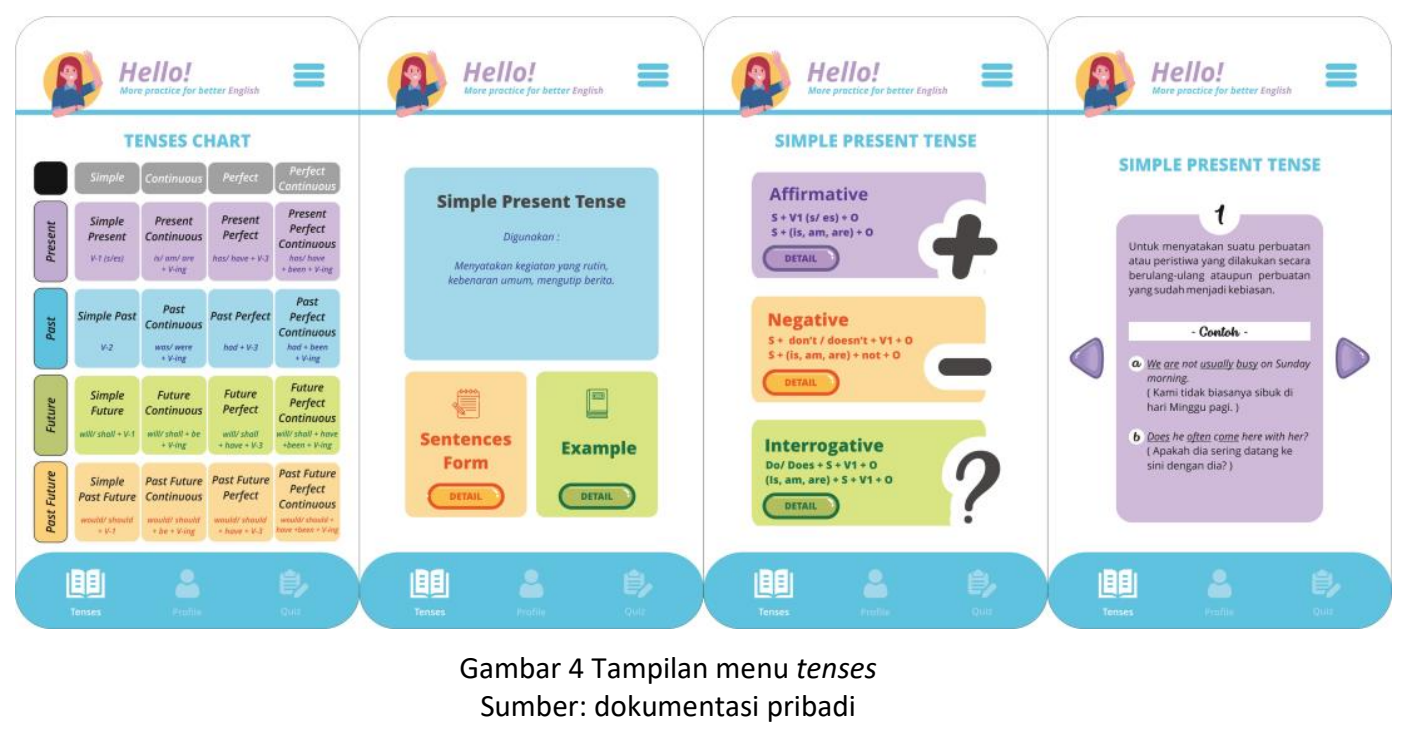


Gambar 4 adalah tampilan menu aplikasi yang menampilkan 16 bentuk tenses yang apabila ditekan salah satu bentuk tenses tersebut akan menampilkan menu pilihan baru yaitu bentuk rumus kalimat, contoh penggunaan dan deskripsi singkat tentang tenses yang dipilih.

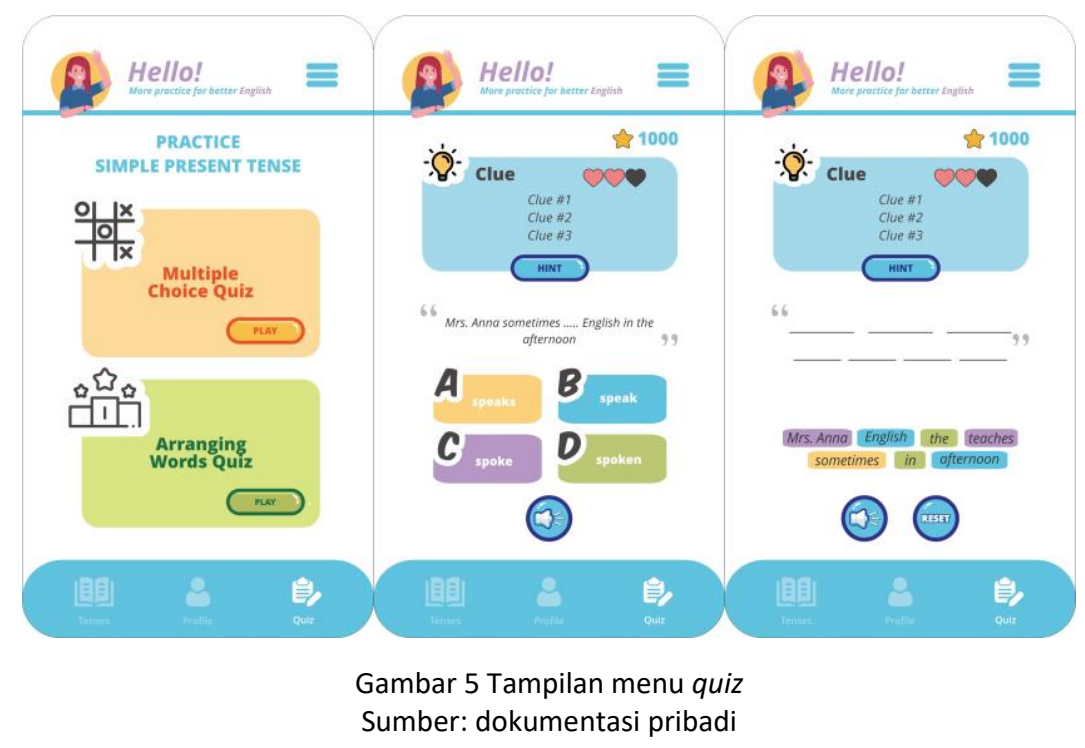

Gambar 5 adalah tampilan menu kuis pada aplikasi yang menampilkan dua pilihan kuis yang tersedia. Pilihan tersebut adalah pilihan ganda dan menyusun kata menjadi kalimat, untuk setiap jawaban yang berhasil dijawab akan mendapatkan poin yang akan ditampilkan pada bagian kanan atas dan pada menu utama.

Pengujian

Aplikasi didistribusikan melalui link Google Play (https://play.google.com/store/apps/details?id=com.nelly.tenses) untuk kemudahan mengunduh dan sosialisasi dilakukan dalam pertemuan online di klub Bahasa Inggris di STMIK STIKOM Indonesia. Gambar 6 merupakan tampilan TensesApp dalam Google Play. 


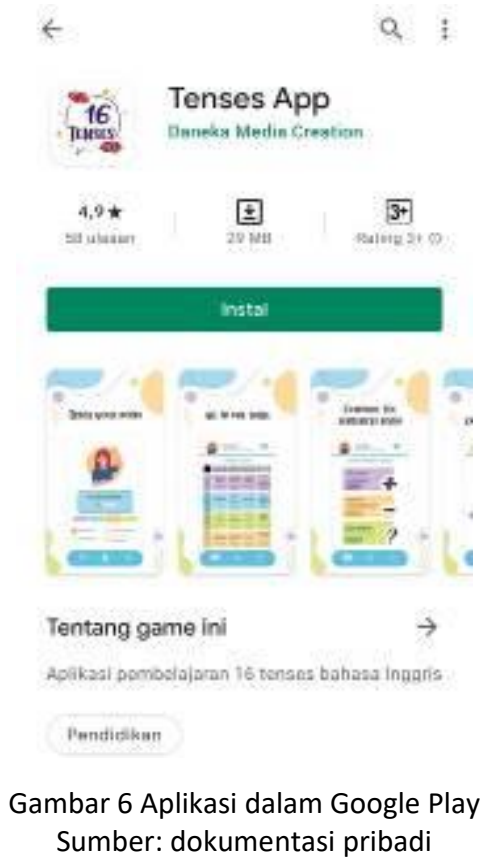

Pengujian menggunakan metode black box, dilakukan untuk menguji fungsi operasional software. Pengajuan dilakukan oleh dosen Bahasa Inggris dan mahasiswa. Pengujian oleh dosen dilakukan oleh 3 dosen Bahasa Inggris di STMIK STIKOM Indonesia yaitu ibu Sri Widiastutik, S.S., M.Hum, Ni Putu Dian Indra Pratiwi, S.Pd., M.Pd. dan Kadek Yogi Susana,S.S.,M.Hum. Tabel 12 , dan 3 adalah hasil evaluasi dosen:

Tabel 1 Evaluasi dosen terhadap kesesuaian materi

\begin{tabular}{llllllll}
\hline No & \multicolumn{1}{c}{ Pertanyaan } & $\begin{array}{c}\text { STS } \\
\text { (Skor } \\
\text { 1) }\end{array}$ & $\begin{array}{c}\text { TS } \\
\text { (Skor } \\
\text { 2) }\end{array}$ & $\begin{array}{c}\text { KS } \\
\text { (Skor } \\
\text { 3) }\end{array}$ & $\begin{array}{c}\text { S } \\
\text { (Skor } \\
\text { 4) }\end{array}$ & $\begin{array}{c}\text { SS } \\
\text { (Skor } \\
\text { 5) }\end{array}$ & \% \\
\hline $\mathbf{1}$ & $\begin{array}{l}\text { Materi yang disajikan sudah sesuai } \\
\text { untuk level mahasiswa? }\end{array}$ & 0 & 0 & 0 & 0 & 3 & $100 \%$ \\
\hline $\mathbf{2}$ & $\begin{array}{l}\text { Apakah tabel rumus tenses yang } \\
\text { disajikan sudah benar dan sesuai? }\end{array}$ & 0 & 0 & 0 & 3 & 0 & $80 \%$ \\
\hline $\mathbf{3}$ & $\begin{array}{l}\text { Apakah menu contoh rumus tenses } \\
\text { yang disajikan sudah benar dan sesuai? }\end{array}$ & 0 & 0 & 0 & 3 & 0 & $80 \%$ \\
\hline $\mathbf{4}$ & $\begin{array}{l}\text { Apakah menu contoh kalimat tenses } \\
\text { yang disajikan sudah benar dan sesuai? }\end{array}$ & 0 & 0 & 0 & 2 & 1 & $86,7 \%$ \\
\hline $\mathbf{5}$ & $\begin{array}{l}\text { Apakah materi pada menu tambahan: } \\
\text { pronouns mudah dipahami? }\end{array}$ & 0 & 0 & 0 & 3 & 0 & $80 \%$ \\
\hline
\end{tabular}




\begin{tabular}{clcccccc}
\hline 6 & $\begin{array}{l}\text { Apakah materi pada menu tambahan: } \\
\text { prepositions mudah dipahami? }\end{array}$ & 0 & 0 & 0 & 2 & 1 & $86,7 \%$ \\
\hline $\mathbf{7}$ & $\begin{array}{l}\text { Apakah materi pada menu tambahan: } \\
\text { question words mudah dipahami? }\end{array}$ & 0 & 0 & 0 & 2 & 1 & $86,7 \%$ \\
\hline $\mathbf{8}$ & $\begin{array}{l}\text { Apakah menu latihan soal pilihan ganda } \\
\text { mudah dikerjakan? }\end{array}$ & 0 & 0 & 0 & 3 & 0 & $80 \%$ \\
\hline $\mathbf{9}$ & $\begin{array}{l}\text { Apakah menu latihan soal menyusun } \\
\text { kata mudah dikerjakan? }\end{array}$ & 0 & 0 & 1 & 2 & 0 & $73,4 \%$ \\
\hline & Sumber: dokumentasi pribadi & & Rata-rata & $83,7 \%$ \\
\hline
\end{tabular}

Tabel 2 Evaluasi dosen terhadap User Interface

\begin{tabular}{cccccccc}
\hline No & Pertanyaan & $\begin{array}{c}\text { STS } \\
\text { (Skor } \\
\text { 1) }\end{array}$ & $\begin{array}{c}\text { TS } \\
\text { (Skor } \\
\text { 2) }\end{array}$ & $\begin{array}{c}\text { KS } \\
\text { (Skor } \\
\text { 3) }\end{array}$ & $\begin{array}{c}\text { S } \\
\text { (Skor } \\
\text { 4) }\end{array}$ & $\begin{array}{c}\text { SS } \\
\text { (Skor }\end{array}$ & \% \\
\hline $\mathbf{1}$ & $\begin{array}{l}\text { Apakah aplikasi menarik, tidak terlalu } \\
\text { kaku untuk digunakan? }\end{array}$ & 0 & 0 & 0 & 2 & 1 & $86,7 \%$ \\
\hline \multicolumn{7}{c}{ Sumber: dokumentasi pribadi }
\end{tabular}

Tabel 3 Evaluasi dosen terhadap User Experience

\begin{tabular}{|c|c|c|c|c|c|c|c|}
\hline No & Pertanyaan & $\begin{array}{l}\text { STS } \\
\text { (Skor } \\
\text { 1) }\end{array}$ & $\begin{array}{l}\text { TS } \\
\text { (Skor } \\
\text { 2) }\end{array}$ & $\begin{array}{l}\text { KS } \\
\text { (Skor } \\
3 \text { ) }\end{array}$ & $\begin{array}{l}\text { S } \\
\text { (Skor } \\
\text { 4) }\end{array}$ & $\begin{array}{l}\text { SS } \\
\text { (Skor } \\
5 \text { ) }\end{array}$ & $\%$ \\
\hline 1 & $\begin{array}{l}\text { Apakah suara pelafalan kalimat } \\
\text { terdengar jelas? }\end{array}$ & 0 & 0 & 0 & 2 & 1 & $86,7 \%$ \\
\hline 2 & $\begin{array}{l}\text { Apakah tombol aplikasi sudah berfungsi } \\
\text { dengan baik? }\end{array}$ & 0 & 0 & 0 & 1 & 2 & $93,4 \%$ \\
\hline 3 & Apakah aplikasi mudah digunakan? & 0 & 0 & 0 & 1 & 2 & $93,4 \%$ \\
\hline 4 & $\begin{array}{l}\text { Apakah aplikasi ini layak untuk dijadikan } \\
\text { aplikasi pendukung pembelajaran } \\
\text { Bahasa Inggris di STMIK STIKOM } \\
\text { Indonesia? }\end{array}$ & 0 & 0 & 0 & 1 & 2 & $93,4 \%$ \\
\hline
\end{tabular}

Sumber: dokumentasi pribadi 


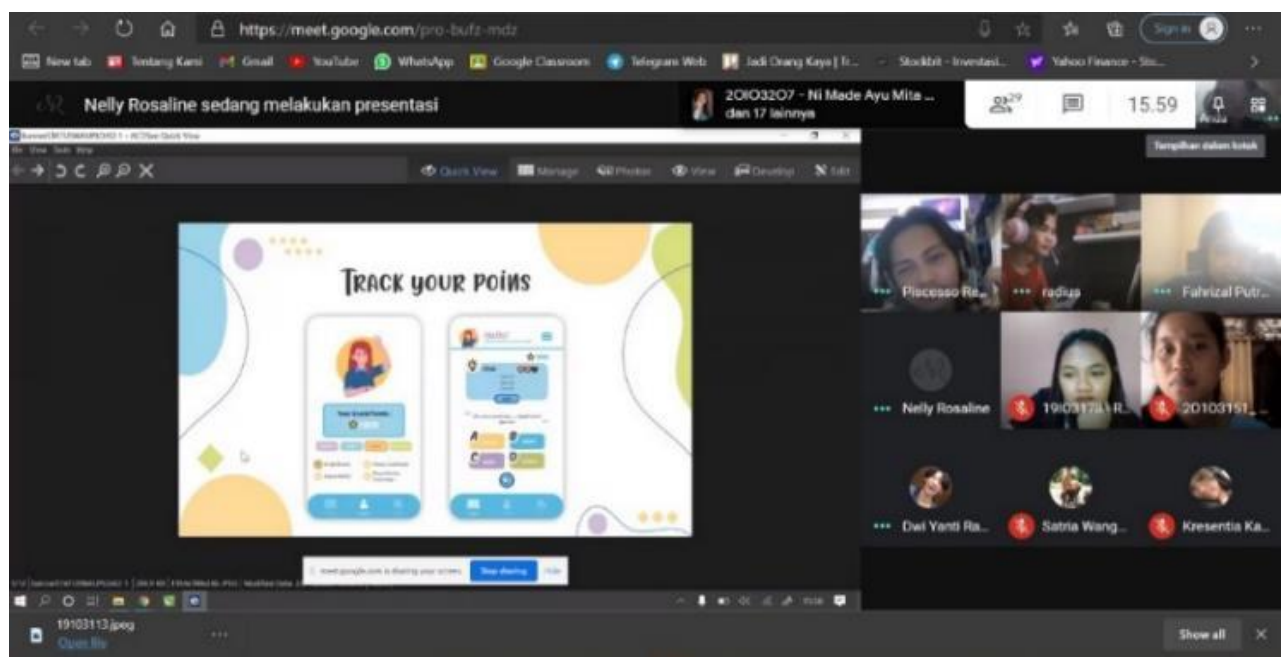

Gambar 7 Sosialisasi aplikasi secara online Sumber: dokumentasi pribadi

Pada gambar 7, pengujian dilakukan oleh 50 sampel mahasiswa STMIK STIKOM Indonesia dalam sosialisasi pertemuan online, ulasan untuk aplikasi disebarkan menggunakan Google Form. Tabel 4, 5, dan 6 adalah hasil evaluasi dari mahasiswa STMIK STIKOM Indonesia:

Tabel 4 Evaluasi mahasiswa terhadap materi

\begin{tabular}{|c|c|c|c|c|c|c|c|}
\hline No & Pertanyaan & $\begin{array}{l}\text { STS } \\
\text { (Skor } \\
\text { 1) }\end{array}$ & $\begin{array}{l}\text { TS } \\
\text { (Skor } \\
\text { 2) }\end{array}$ & $\begin{array}{l}\text { KS } \\
\text { (Skor } \\
3 \text { ) }\end{array}$ & $\begin{array}{l}\text { S } \\
\text { (Skor } \\
4)\end{array}$ & $\begin{array}{l}\text { SS } \\
\text { (Skor } \\
5 \text { ) }\end{array}$ & $\%$ \\
\hline 1 & $\begin{array}{l}\text { Apakah tabel rumus tenses yang } \\
\text { disajikan mudah dimahami? }\end{array}$ & 0 & 0 & 0 & 13 & 37 & $94,8 \%$ \\
\hline 2 & $\begin{array}{l}\text { Apakah menu contoh rumus tenses } \\
\text { yang disajikan mudah dimahami? }\end{array}$ & 0 & 0 & 0 & 17 & 33 & $93,8 \%$ \\
\hline 3 & $\begin{array}{l}\text { Apakah menu contoh kalimat tenses } \\
\text { yang disajikan mudah dipahami? }\end{array}$ & 0 & 0 & 4 & 23 & 23 & $87,6 \%$ \\
\hline 4 & $\begin{array}{l}\text { Apakah materi pada menu tambahan: } \\
\text { pronouns mudah dipahami? }\end{array}$ & 0 & 0 & 1 & 13 & 36 & $94 \%$ \\
\hline 5 & $\begin{array}{l}\text { Apakah materi pada menu tambahan: } \\
\text { prepositions mudah dipahami? }\end{array}$ & 0 & 0 & 0 & 16 & 34 & $93,6 \%$ \\
\hline 6 & $\begin{array}{l}\text { Apakah materi pada menu tambahan: } \\
\text { question words mudah dipahami? }\end{array}$ & 0 & 0 & 0 & 19 & 31 & $92,4 \%$ \\
\hline 7 & $\begin{array}{l}\text { Apakah menu latihan soal pilihan } \\
\text { ganda mudah dikerjakan? }\end{array}$ & 0 & 0 & 4 & 28 & 18 & $85,6 \%$ \\
\hline 8 & $\begin{array}{l}\text { Apakah menu latihan soal menyusun } \\
\text { kata mudah dikerjakan? }\end{array}$ & 0 & 0 & 8 & 25 & 17 & $83,6 \%$ \\
\hline & & & & & \multicolumn{2}{|c|}{ Rata-rata } & $91,9 \%$ \\
\hline
\end{tabular}


Tabel 5 Evaluasi Mahasiswa terhadap User Interface

\begin{tabular}{|c|c|c|c|c|c|c|c|}
\hline No & Pertanyaan & $\begin{array}{c}\text { STS } \\
\text { (Sko } \\
\text { r 1) }\end{array}$ & $\begin{array}{c}\text { TS } \\
\text { (Skor } \\
\text { 2) }\end{array}$ & $\begin{array}{c}\text { KS } \\
\text { (Skor } \\
\text { 3) }\end{array}$ & $\begin{array}{c}\text { S } \\
\text { (Sko } \\
\text { r 4) }\end{array}$ & $\begin{array}{c}\text { SS } \\
\text { (Sko } \\
\text { r 5) }\end{array}$ & $\%$ \\
\hline 1 & $\begin{array}{l}\text { Apakah aplikasi menarik, tidak terlalu } \\
\text { kaku untuk digunakan? }\end{array}$ & 0 & 0 & 0 & 6 & 44 & $97,6 \%$ \\
\hline & & & & & \multicolumn{2}{|c|}{ Rata-rata } & $97,6 \%$ \\
\hline
\end{tabular}

Tabel 6 Evaluasi Mahasiswa terhadap User Experience

\begin{tabular}{|c|c|c|c|c|c|c|c|}
\hline No & Pertanyaan & $\begin{array}{l}\text { STS } \\
\text { (Skor } \\
\text { 1) }\end{array}$ & $\begin{array}{l}\text { TS } \\
\text { (Skor } \\
\text { 2) }\end{array}$ & $\begin{array}{l}\text { KS } \\
\text { (Skor } \\
3 \text { ) }\end{array}$ & $\begin{array}{l}\text { S } \\
\text { (Skor } \\
4 \text { ) }\end{array}$ & $\begin{array}{l}\text { SS } \\
\text { (Skor } \\
5 \text { ) }\end{array}$ & $\%$ \\
\hline 1 & $\begin{array}{l}\text { Apakah suara pelafalan kalimat } \\
\text { terdengar jelas? }\end{array}$ & 0 & 0 & 8 & 29 & 13 & $82 \%$ \\
\hline 2 & $\begin{array}{l}\text { Apakah tombol aplikasi sudah } \\
\text { berfungsi dengan lancar dan sesuai? }\end{array}$ & 0 & 0 & 0 & 11 & 39 & $95,6 \%$ \\
\hline 3 & Apakah aplikasi mudah digunakan? & 0 & 0 & 0 & 13 & 37 & $94,8 \%$ \\
\hline & & & & & \multicolumn{2}{|c|}{ Rata-rata } & $90,8 \%$ \\
\hline
\end{tabular}

Sumber: dokumentasi pribadi

\section{Diskusi}

Penelitian ini merupakan pengembangan dari dua penelitian terdahulu yang digunakan sebagai acuan. Aplikasi dalam penelitian ini mengembangkan beberapa segi seperti tampilan, materi, latihan soal dan fitur tambahan.

Pada penelitian Susilawati dan Khamadi (2016), aplikasi hanya menyajikan 12 materi tenses dengan latihan soal pilihan ganda secara menyeluruh untuk semua materi tenses yang disajikan. Pada penelitian Makmun (2017), aplikasi sudah menyajikan 16 materi tenses tetapi hanya menyajikan satu latihan soal menulis kalimat yang benar untuk masingmasing jenis tensesnya, juga menyajikan keterangan kapan tenses tersebut dipakai tetapi belum menyajikan contoh-contoh kalimat tenses yang digunakan sesuai kondisi kegiatan yang dilakukan.

Penelitian ini menyajikan 16 materi tenses dengan mengembangkan jenis dan jumlah latihan soal yaitu, lima latihan soal pilihan ganda dan lima 
soal menyusun kata menjadi kalimat untuk masing-masing jenis tenses dan juga ditambahkan fitur audio pengucapan kalimat untuk melatih kemampuan mendengarkan pada setiap latihan soalnya. Selain itu, ditambahkan menu tersendiri untuk membahas contoh kalimat tenses dalam beberapa kondisi kegiatan dan menu untuk menyajikan rumus kalimat tenses serta contoh kalimat sesuai rumus tenses yang ditampilkan, semua itu dikemas dalam tampilan aplikasi yang lebih playful.

Menu tampilan yang playful dan ragam latihan soal yang ditawarkan serta poin record yang ditampilkan membuat pengguna (mahasiswa) dalam pengujiannya terlihat antusias untuk mengumpulkan poin sebanyakbanyaknya dari menjawab soal yang ditampilkan pada menu latihan soal. Hal ini dapat menjadi metode untuk merangsang pengguna dalam penggunaan berkelanjutan.

Berbeda dengan dua penelitian sebelumnya yang masih menggunakan desain skeuomorphism untuk tampilan UI pada aplikasinya (lihat Gambar 8), pada penelitian ini beralih ke tampilan flat design (lihat Gambar 9). Kebutuhan untuk menampilkan citra yang lebih tajam menjadikan flat design lebih digemari karena lebih mudah untuk menampilkan gambar tunggal dengan tipografi.

Adapun kekurangan nyata penggunaan flat design dalam penerapan desain UI, seperti menghilangkan petunjuk visual yang diperlukan untuk menentukan apakah ada sesuatu yang dapat diklik atau tidak (Hasanudin \& Adityawan, 2020). Pada penelitian ini, tampilan menu tabel 16 tenses (Gambar 4, paling kiri) terlihat minimalis karena menggunakan penyederhanaan bentuk dalam penerapan flat design, karena hal tersebut pengguna sedikit kesulitan untuk memahami bahwa setiap tenses yang disajikan pada tabel tersebut merupakan tombol yang bisa diklik untuk mengakses menu berikutnya. 


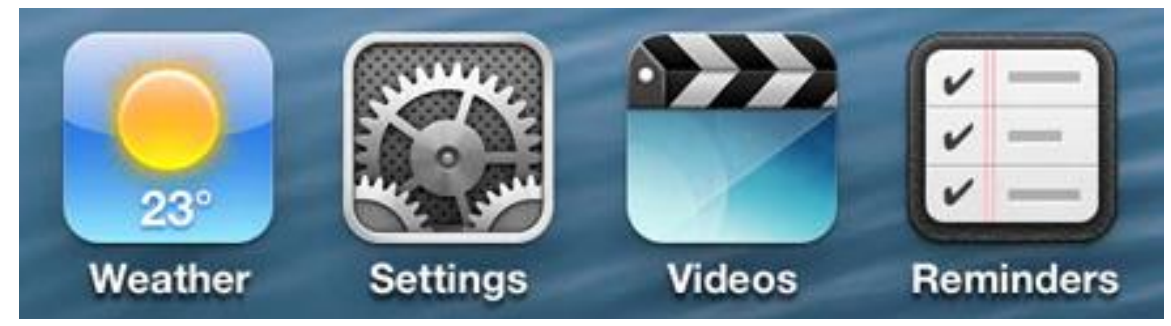

Gambar 8 Skeuomorphism dalam desain UI Sumber: Workerbee (2016)

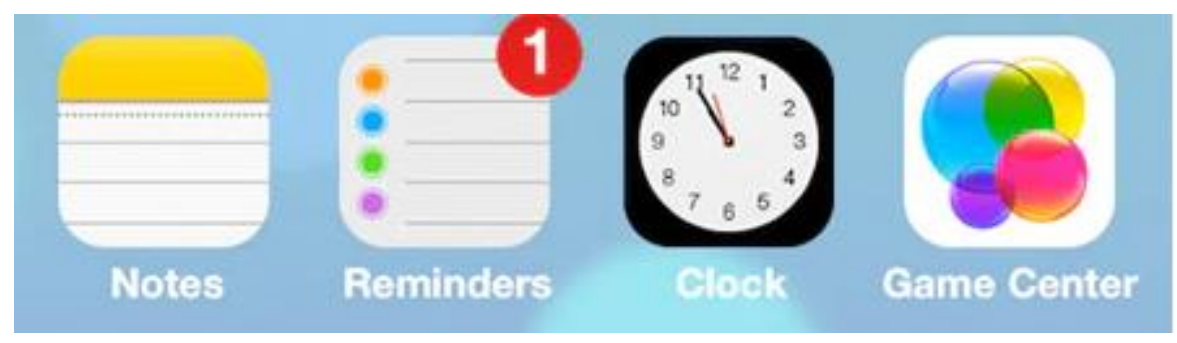

Gambar 9 Flat design dalam desain UI Sumber: Workerbee (2016)

Secara keseluruhan aplikasi ini menjadi media praktis dalam proses belajar mengajar Bahasa Inggris baik di dalam kelas maupun di luar jam kelas, karena aplikasi ini merupakan media belajar yang ringkas tanpa batasan waktu dan tempat dibandingkan dengan media belajar buku yang konvensional.

\section{KESIMPULAN}

Peningkatan keterampilan bahasa asing khususnya Bahasa Inggris untuk menghadapi persaingan global, apalagi dalam situasi pandemi COVID19 (Corona Virus Disease 2019), yang mengharuskan proses belajar mengajar dengan media daring menuntut generasi muda untuk harus lebih proaktif dalam belajar secara mandiri menggunakan gawai masing-masing.

Berdasarkan hasil pengumpulan data primer dan sekunder didapatkan bahwa di STMIK STIKOM Indonesia memiliki organisasi peminatan Bahasa Inggris dan di pelajaran formal juga ada mata kuliah khusus tentang Bahasa Inggris untuk mengembangkan keterampilan Bahasa Inggris mahasiswanya. 
Pelajaran Bahasa Inggris meliputi beberapa elemen salah satunya yaitu struktur bahasa (grammar), yang teorinya berkenaan tentang tenses. Pelajaran tenses yang dikemas dalam bentuk aplikasi mobile berbasis Android memiliki keunggulan, seperti praktis dan interaktif, serta tanpa batasan waktu dan tempat dalam penggunaannya.

Penelitian ini berhasil menghasilkan media pembelajaran 16 tenses Bahasa Inggris berbasis Android yang berhasil diunggah dalam Google Playstore untuk kemudahan mengunduh dan didistribusikan pada pertemuan online dalam klub Bahasa Inggris STMIK STIKOM Indonesia sebagai pengujian.

Berdasarkan hasil dari evaluasi 3 dosen Bahasa Inggris dapat disimpulkan bahwa konten dan materi yang disajikan dalam aplikasi sudah benar dan sesuai untuk tingkat mahasiswa. Aplikasi dapat digunakan dengan mudah dan aplikasi pembelajaran 16 tenses ini sangat direkomendasikan untuk dijadikan aplikasi pendukung pembelajaran Bahasa Inggris di STMIK STIKOM Indonesia.

Berdasarkan hasil dari evaluasi 50 sampel mahasiswa dapat disimpulkan bahwa konten dan materi yang disajikan dalam aplikasi sangat mudah dipahami, soal pada menu kuis dapat dengan mudah dijawab. Aplikasi dapat mengeluarkan suara pelafalan kalimat yang terdengar dengan jelas, tombol aplikasi sudah berfungsi dengan lancar dan sesuai, dan aplikasi sangat mudah serta menarik untuk digunakan.

Penelitian yang dilakukan tentunya tidak lepas dari kekurangan. Limitasi pada penelitian ini adalah keterbatasan proses pengujian kepada mahasiswa dalam situasi pandemi COVID-19 (Corona Virus Disease 2019) yang mengharuskan pengujian dilakukan secara online, di mana tidak semua partisipan bisa bergabung dalam proses pengujian tersebut secara langsung dikarenakan keterbatasan koneksi masing-masing. Selain itu, tidak semua 
partisipan menggunakan ponsel Android, sehingga partisipan yang menggunakan iOS tidak bisa ikut dalam pengujian aplikasi pada penelitian ini.

Adapun saran untuk pengembangan penelitian ini yaitu; penelitian dikembangkan dengan menambahkan lebih banyak soal dan jenis latihan soal. Mencari jenis-jenis media pembelajaran atau alat bantu pembelajaran lain selain aplikasi berbasis Android. Aplikasi dapat diunggah juga di Appstore untuk pengguna iOS atau dibuat dalam versi web sehingga dapat diakses melalui perangkat apapun tanpa harus mengunduh aplikasi terlebih dahulu. Pada segi visualisasi, aplikasi dapat mengeksplorasi gaya desain selain flat design yang sudah terlalu biasa digunakan.

\section{DAFTAR PUSTAKA}

Antare, I. G. N. P. R., \& Setiawan, I. K. (2021). Cerita Bergambar 'Men Tiwas Teken Men Sugih' Berbasis Android. Desain Komunikasi Visual, Manajemen Desain Dan Periklanan (Demandia), 6(1), 132. https://doi.org/10.25124/demandia.v6i1.3399

CNN Indonesia. (2019). Empat Industri Potensial RI Hadapi Persaingan Global. Retrieved from https://www.cnnindonesia.com/ekonomi/20191007222219-97437609/empat-industri-potensial-ri-hadapi-persaingan-global

EF Education First. (2019). EF English Proficiency Index: A Ranking of 100 Countries and Regions by English Skills. Retrieved from https://www.ef.co.id/epi/

Ekayani, N. L. P. (2017). Pentingnya Penggunaan Media Pembelajaran Untuk Meningkatkan Prestasi Belajar Siswa. Jurnal Fakultas IImu Pendidikan, 2(1), 1-11.

Hasanudin, D., \& Adityawan, O. (2020). Perkembangan Flat Design dalam Web 
Design dan User Interface ( UI ). Pantun Jurnal IImiah Seni Budaya, 5(2), 134-144.

Kurniawati, I. D., \& Nita, S. (2018). Media Pembelajaran Berbasis Multimedia Interaktif Untuk Meningkatkan Pemahaman Konsep Mahasiswa. DoubleClick: Journal of Computer and Information Technology, 1(2), 68. https://doi.org/10.25273/doubleclick.v1i2.1540

Makmun. (2017). Aplikasi Pembelajaran Tenses dan Passive Voice berbasis Android. Jurnal IImiah KOMPUTASI, 16(2), 151-160.

Megawati, F. (2016). Kesulitan Mahasiswa Dalam Mencapai Pembelajaran Bahasa Inggris Secara Efektif. JURNAL PEDAGOGIA, 5(2), 147-156.

Merliana, N. P. E. (2019). Pemanfaatan Teknologi Informasi Berbasis Android Sebagai Media dalam Pembelajaran Hindu. Satya Widya: Jurnal Studi Agama, 1(1), 37-53. https://doi.org/10.33363/swjsa.v1i1.54

Natalia, S. A. M. K. D., \& Setiawan, I. K. (2020). Pengembangan Media Pembelajaran Bahasa Inggris Dasar Berbasis Android untuk Kelas V Sekolah Dasar. Jurnal Nawala Visual, 2(1), 9-19. https://doi.org/10.35886/nawalavisual.v2i1.56

Nuriansyah, F. (2020). Efektifitas Penggunaan Media Online Dalam Meningkatkan Hasil Belajar Pada Mahasiswa Pendidikan Ekonomi Saat Awal Pandemi Covid-19. Jurnal Pendididikan Ekonomi Indonesia, 1(2), $61-65$. Retrieved from

https://ejournal.upi.edu/index.php/JPEl/article/view/28346

Prastowo, P. (2016). Kiat cepat kuasai grammar dan 16 tenses. Yogyakarta Laksana.

Putri, K. E., \& Sahari, S. (2017). Pengembangan Media Pembelajaran Berbasis Android Pada Mata Kuliah Pembelajaran Terpadu. Jurnal PINUS, 3(1), 3240. https://doi.org/10.1017/СBO9781107415324.004

Putu, N., Dewi, S., \& Setiawan, I. K. (2020). Pengenalan Cerita Rakyat I Gede 
Basur Melalui Cerita Bergambar, 2(2), 70-78.

Statcounter. (2021). Mobile Operating System Market Share Worldwide - May 2021. Retrieved from https://gs.statcounter.com/os-marketshare/mobile/worldwide

Susilawati, E., \& Khadami, A. Y. (2016). Aplikasi Pembelajaran Tenses Dalam Bahasa Inggris Berbasis Android Di Smkn 9 Bandung. Jurnal Manajemen Informatika, 6, 27-31.

Workerbee. (2016). Skeuomorphism vs. Flat Design vs Material Design. Retrieved from https://99designs.com/blog/trends/skeuomorphismflat-design-material-design/ 